\title{
A Dilemma of Abundance: Governance Challenges of Reconciling Shale Gas Development and Climate Change Mitigation
}

\section{Eleanor Stephenson and Karena Shaw *}

School of Environmental Studies, University of Victoria, Victoria V8W 3R4, Canada; E-Mail: e.stephenson@oxon.org

* Author to whom correspondence should be addressed; E-Mail: shawk@uvic.ca; Tel.: +250-721-7353.

Received: 18 March 2013; in revised form: 24 April 2013 / Accepted: 28 April 2013/ Published: 14 May 2013

\begin{abstract}
Shale gas proponents argue this unconventional fossil fuel offers a "bridge" towards a cleaner energy system by offsetting higher-carbon fuels such as coal. The technical feasibility of reconciling shale gas development with climate action remains contested. However, we here argue that governance challenges are both more pressing and more profound. Reconciling shale gas and climate action requires institutions capable of responding effectively to uncertainty; intervening to mandate emissions reductions and internalize costs to industry; and managing the energy system strategically towards a lower carbon future. Such policy measures prove challenging, particularly in jurisdictions that stand to benefit economically from unconventional fuels. We illustrate this dilemma through a case study of shale gas development in British Columbia, Canada, a global leader on climate policy that is nonetheless struggling to manage gas development for mitigation. The $\mathrm{BC}$ case is indicative of the constraints jurisdictions face both to reconcile gas development and climate action, and to manage the industry adequately to achieve social licence and minimize resistance. More broadly, the case attests to the magnitude of change required to transform our energy systems to mitigate climate change.
\end{abstract}

Keywords: climate change; shale gas; energy systems; regulation; governance 


\section{Introduction}

Mitigating climate change presents a profound challenge, not least because both our physical and political infrastructure are structured around fossil fuels that still comprise over $80 \%$ of world energy use [1]. There is broad consensus across academic literature that global energy use must rise to improve energy equity, while at the same time global fossil fuel emissions must decline to avert dangerous climate change: the International Energy Agency (IEA) estimated in 2012 that only one third of proven global fossil fuel reserves can be consumed, if we are to limit global warming to $2{ }^{\circ} \mathrm{C}$, barring widespread deployment of carbon capture and storage [1]. Despite ongoing calls to reshape energy systems, fossil fuel use continues to rise [2], and many jurisdictions are expanding production along new frontiers to meet growing demand. For example, deepwater, arctic, superdeep, heavy oil bitumen, and oil shale resources are already contributing or may soon contribute to global oil supplies, while shale, tight sands, and coal seam gas contribute to global gas supplies [3].

The first unconventional source to enter widespread production is shale gas, obtained from underground shale rock formations using new horizontal drilling and hydraulic fracturing technologies that have rendered competitive sources previously dismissed as uneconomical [4]. Shale gas has created an energy boom that is already transforming energy systems in North America, with cascading effects worldwide. In North America, shale gas has been widely characterized as a positive "game changer," moving the continent from a net gas importer towards self-sufficiency and possibly even export amidst the deepest recession in decades. Shale gas production is now expanding to the United Kingdom, Poland, Australia, Qatar, South Africa, and China [1]. Globally, shale gas could be a significant contributor to growing global energy needs, with gas consumption expected to increase by $44 \%$ between 2010 and 2035 [5].

This unprecedented global shift brings with it commensurate risks and opportunities for climate change mitigation. Critics note that by developing unconventional sources we risk creating more path-dependent fossil fuel infrastructure, maintaining fossil fuel supply at a higher Energy Return on Investment, and impacting sensitive ecosystems from the Greenlandic Arctic to South African Karoo that have little history of fossil fuel development and may already be adversely affected by climate change. However, the IEA, among others, suggests that shale gas can form part of a medium-term transition to clean energy sources by creating a cost-competitive and lower-carbon alternative to coal, the most carbon-intensive, abundant, and inexpensive of fossil fuels [6]. The IEA's most ambitious scenarios for greenhouse gas reductions call for increased global natural gas production [1,7]. Numerous jurisdictions appeal to this logic in support of development, suggesting shale gas will be an essential "bridging fuel" towards renewable energy.

In what follows, we identify the core technical and governance [8] challenges of reconciling increased shale gas development with climate change mitigation. We find that policy measures to do so are falling short, with current institutions constrained in their capacity to regulate the industry; hesitant to impose costs, actively control or manage development; and threatened by the fiercely competitive international market. At the same time, public resistance to the environmental and economic deal offered by unchecked development is growing, and may thwart ambitions for rapid development. Combined, these conditions present a vexing dilemma for the state. We illustrate how these interlinked technical and governance challenges manifest in one jurisdiction caught on the horns 
of the shale gas dilemma: the province of British Columbia, Canada. A global leader on climate policy, the Province nonetheless shows little inclination or ability to manage development adequately for climate mitigation, illustrating the magnitude of environmental governance challenges faced by jurisdictions developing shale gas resources.

Although conditions vary across jurisdictions, the essential point is transferable: in the context of climate change, shale gas requires new kinds of institutions and governance capacity, bringing to light core challenges of transforming our energy systems to mitigate climate change. We acknowledge that reducing dependency on oil and coal poses commensurate challenges, and our analysis does not dismiss the possibility of shale gas serving the needs of climate mitigation under some conditions; rather, we argue that reconciling shale gas and climate action must be engaged as a governance challenge, and attempt to sketch out that challenge.

\section{Technical and Governance Challenges of Shale Gas Development}

To date, academic literature and international organizations have emphasized the technical challenges of managing shale gas development safely. This first wave of analysis has generated answers, and further questions, about the relative impacts of shale gas compared to conventional gas, coal, or renewables [9-17]; has modeled various climate scenarios to show how the rise of natural gas affects the trajectory of greenhouse gas emissions [15,18]; and has produced case studies on watershed impacts, contamination and public health $[19,20]$. These studies reach divided conclusions, drawing attention to both prospective benefits (such as reduced emissions and reduced particulate) and concerns about shale gas (notably increased emissions under some scenarios and water quality, ecosystem and health impacts). Emerging literature addresses some of the governance challenges associated with shale gas development, including economic dynamics [21,22] and the capacity of different regulatory regimes $[23,24]$. In this section, we synthesize existing literature to explore both the technical and governance challenges specific to reconciling shale gas with climate mitigation. We suggest this would require at a minimum a concerted focus on three sets of challenges: responding effectively to uncertainty, reshaping the political-economic context towards emissions reductions, and planning for long-term energy system transformation.

\subsection{Responding Effectively to Uncertainty}

While politicians label natural gas as a "clean energy source," scientific uncertainty about the climate impacts of unconventional gas development remains, posing both technical and governance challenges. Debate is driven by uncertainty about input variables used to calculate the emissions factors of shale gas. The IEA [6] bases their scenarios on the assumption that, over a 100-year warming period, shale gas is $3.5 \%-12 \%$ more emissions-intensive than conventional gas [25] and consequently preferable to coal. While such estimates guide policy worldwide, the exact benefit of shale gas over coal remains contested [26].

Fugitive methane emissions or "leakage" [27] from shale gas production is the primary source of uncertainty and controversy. While some studies suggest fugitive emissions are similar for conventional gas and shale gas - or even that shale gas has a lower emissions factor than conventional gas [16] - there is some consensus that shale gas emissions, in general, are somewhat higher 
than conventional gas, primarily because of increased fugitive emissions during flowback of fracking fluids [24]. Because such fugitive emissions are methane, a greenhouse gas 23 times more potent than carbon dioxide $[28,29]$, the emissions factor of natural gas is highly sensitive to the level of fugitive emissions. Recent studies have suggested that for shale gas developments to offer benefits over coal, they must leak methane at a rate of less than 3.2\% of total well production [18]. Models offer various estimates of leakage rates: $1.7 \%-6 \%$ [9], 3\%-6\% [30], 2.4\% [20], 2.01\% [16], and 3\% [18]. Direct field measurements are scarce, with $4.38 \%$ leakage reported at a field site near Boulder, Colorado [31], and most recently $9 \%$ leakage reported for the Uinta Basin of Utah [32]. Pinning down these figures is more challenging than expected. Heterogeneous geological conditions make it difficult to generalize about emissions of gas development (see $[18,31,33]$ ). The ultimate recovery of wells is also contested, with several studies showing shale wells depleting faster than early projections $[21,34]$. This has drawn attention because of its implications for economic viability and investor confidence in the industry [21,22,35], but also has implications for emissions, which are normalized over the well's lifetime production [36].

Policy measures to address these areas of scientific uncertainty range from support for further scientific data collection and assessment to reinforcing or expanding regulatory bodies that provide credible information independent of industry [37]. These measures play necessary roles in providing baseline information for further policy development. For example, researching and updating emissions metrics allows for the creation of more accurate GHG inventories, which provide benchmarks for improvements and inform other policy mechanisms, including carbon pricing. These changes can also have dramatic consequences for how we view climate impacts of gas development: a revision to the Environmental Protection Agency's (EPA's) emissions factor for natural gas in 2011 [20] increased total estimated emissions of the natural gas industry by $150 \%$ [13].

However, there are barriers to the state's capacity to effectively address scientific uncertainty. Although further research to better characterize the emissions of specific regions is underway [38], this research takes time. The need for improved baseline science on shale gas emissions (and other impacts) would suggest the wisdom of a precautionary approach through carefully managed and moderately-paced development. Yet many jurisdictions with unconventional resources also have little experience or capacity to navigate the pressures of the fast moving and powerful international fossil fuel industry. Across North America, states and provinces have the authority to decide on whether to allow shale gas expansion; however they have few regulatory options that can keep up with the pace of competition, short of an outright ban [39]. As a result, they have tended towards either speedy opt-in or towards complete opt-out by delaying production (as in New York state and the province of Quebec) [24]. Optimistically, some argue that regulating shale gas may prove easier where existing states are not already dependent on fossil fuel revenue or beholden to privilege these industries [23]. Less optimistically, where opt-in has been the choice, we are seeing active facilitation of shale gas development that circumvents the types of knowledge production and regulatory oversight described above. For example, rather than the expanded and reinforced capacity called for above [40], several jurisdictions have moved towards rewriting legislation that would apply to shale gas development. In the USA, for example, a 2005 loophole in the Clean Water Act exempts fracking operations from baseline monitoring otherwise required [23], while in Canada, the national government has enacted sweeping changes to the Environmental Assessment Act that will facilitate development for oil and gas operators (discussed in Section 4.2 below). 


\subsection{Reducing Emissions}

While reducing uncertainty marks a crucial goal, managing uncertainty effectively through a no-regrets approach to decision-making is also necessary [41-43]. Among the most crucial of no-regrets policy directions is reducing emissions from the growing industry immediately. There is growing consensus that judicious regulation can achieve this [9,11]. Mitigation possibilities include flaring gas (so that it is released to the atmosphere as carbon dioxide) rather than venting it (as methane). An improvement over flaring gas is the use of green completions/ reduced-emissions completions technologies, which are demonstrated to greatly reduce the emissions intensity of shale gas. For example, a 2010 study by the US General Accountability Office found that green completion technologies are capable of reducing methane emissions by $40 \%$ [44], while Jenner and Lamadrid [24] suggest they could do so by $90 \%$.

Though industry may have other incentives to reduce fugitive emissions, including revenue loss and safety, these are not assured. The policy mechanisms for reshaping the political-economic context towards upstream emissions reductions could vary, but aggressive policies to either regulate or incentivize upstream emissions reductions are necessary. These could begin with regulations to flare rather than vent gas, and ultimately lead to a requirement for green completions. Effective monitoring for compliance with best practices to reduce leaks is also essential; as Jenner and Lamadrid [24] suggest, "compliance requires political action in the form of market interference. Without clear signals, some operators will keep on free-riding on the public goods of health, safety, and environmental protection".

While no-regrets emissions reductions must occur upstream where gas is produced, they can also be achieved in the way gas is integrated within the broader energy system, by promoting the use of natural gas in applications with best potential for GHG mitigation-namely, fuel switching for coal fired generation. This process has been successful in some jurisdictions where market conditions coincide with the imperative for emissions reductions, including the USA. Elsewhere, market conditions may differ and strategic energy plans that ensure that gas is used to supplant coal will require that governments actively shape development, or, in the eyes of critics, pick winners. Here, carbon pricing could play a crucial role, serving as a necessary market signal to prompt immediate fuel switching in regions still using coal and create a financial liability for operators [17], and yielding a "double dividend" of revenue and climate mitigation [24,45].

Potential regulators face various barriers to implementing these reforms, not least of which is the perception that enacting these measures will impose costs that render the industry uncompetitive. The exact costs of regulation vary across jurisdictions and geological formations; however, the IEA [40] estimates that judicious regulation may add approximately $7 \%$ in financial costs of development of a typical shale-gas well (this estimate is based on not only emissions reductions, but also measuring and disclosing baseline conditions, and engaging local communities; selecting drilling locations to minimize impacts; isolating wells and preventing leaks; treating water responsibly; and coordinating and managing for cumulative effects). The IEA adds that such measures may be necessary to enable the industry to earn a social licence and thus stable operating conditions, and may be recovered through economies of scale.

However, the unprecedented boom in shale gas has flooded the North American market, resulting in gas prices falling to unprecedented lows, and dampening the profitability of the industry for operators 
(who have in turn reduced capital spending on gas, and in some cases, switched rigs to drilling for shale oil), exacerbating the difficulties of imposing new costs. Even where states do choose to impose additional costs, concern over competitiveness may mean these costs come at the expense of public revenue - an equally unpopular prospect for electorates primed with the message that shale gas will be an economic boon. In this context, concerns over competitiveness have led commentators to suggest the most robust environmental policy we can hope for is "hybrid regulation" consisting of self-regulation amongst companies, and imposed regulations on specific issues such as sourcing and disposal of water [24]. Whether such approaches can deliver on needed emissions reductions is an open question.

International cooperation - for example, through effective regional carbon pricing-could help avert a race to the bottom, since in the increasingly internationalized gas market, competitiveness concerns may prevent jurisdictions from imposing costs. International cooperation is also a necessary step towards managing for the unintended consequences of integrating gas into a complex, internationalized energy system. For example, the IEA notes that, "low-priced natural gas is reducing coal use in the United States, freeing up coal for export to Europe (where, in turn, it has displaced higher-priced gas)" [1]. However, international cooperation proves challenging. Plans for a binding global climate mitigation treaty from the United Nations Framework Convention on Climate Change have been deferred to 2020, when the Conference of Parties 17's Durban Platform for Enhanced Action promises a legal mechanism "or an agreed outcome with legal force" [46]. At present, carbon pricing is not in place for fully managing development in major shale-producing regions; as we discuss below, even British Columbia's carbon tax omits upstream emissions from the shale gas industry.

\subsection{Situating Shale Gas within an Energy System Transformation}

Even if judicious regulation and strategic use of shale gas within broader energy systems can help bring down emissions, unfettered development of unconventional gas is not compatible with climate change mitigation aspirations at the global scale. A $2{ }^{\circ} \mathrm{C}$ global average warming threshold was agreed upon in the UNFCCC's Copenhagen Accord of 2009 [46], and while contested, this is the policy guideline for more than 100 countries. The IEA suggests that if we are to achieve an (ambitious) 2 Degree Warming Scenario at the global scale, we would need to accelerate natural gas base-load generating capacity in the short term to replace coal, then reverse this trend and start to use gas increasingly for peaking power as we move to an energy system where base load is dominated by nuclear and intermittent renewables, and fossil fuels with CCS [1,7]. In some cases, this transition away from base-load generation will need to occur before the natural lifespan of physical infrastructure (natural gas plants have more than a 25-year lifespan); under the two degrees scenario, by 2025 our energy system as a whole would reach an average carbon intensity lower than the average of natural gas, at which time it will be a "high carbon" fuel relative to the desired average [7]. Even under the less ambitious 4 Degree Scenario, gas will be considered "high carbon" by 2040, and base load gas must ultimately be curbed in favour of peaking power [7].

These scenarios suggest that if we are to mitigate climate change effectively, fitting shale gas into an energy system transformation will require strategic planning, both to ensure it displaces coal, and to prevent stranded assets and over construction [7]. Stranded assets include operational power plants, pipelines, and distribution networks that are not yet at the end of their lifespan, but which are no longer 
needed as part of a low carbon energy system. The path dependency of fossil fuel infrastructure can, in some cases, be managed towards a cleaner energy system, for example through the eventual use of hydrogen and biogas within existing natural gas infrastructure, and through the potential incorporation of carbon capture and storage [7]. However, such changes in the overall energy system require fundamental transformations to path-dependent infrastructure and take place on a multi-decadal time scale $[47,48]$. Actively shaping a structural energy system transition poses first an analytical systems problem, with challenges of unpredictability (about future constraints and demands on the energy system, technological developments, the level of international ambition for climate mitigation, unintended consequences, etc.) and sub-optimization (i.e., the difficulty of optimizing emissions reductions at different scales under overlapping governance regimes).

Even if these technical challenges can be addressed, transitioning away from a lucrative resource before it is exhausted is inherently challenging, if not unprecedented. In the event that natural gas supplies, especially from unconventional sources, remain cheap and abundant, it will be difficult for states to convert or bring infrastructure off-line in favour of sources with lower emissions, entrenching economic and energy dependency on fossil fuels. At the same time, preparing to transition away from such sources may raise the same concerns about undermining competitiveness noted above, especially in an internationalized industry, and intensify pressure to rapidly exploit shale reserves to the full extent possible. Averting economic dependence may be more difficult still, requiring long term planning for economic stability, such as investing in alternative sources of energy and economic prosperity to ease the transition, and preventing structural changes in the economy such as "resource curse" conditions characterized by boom-bust cycles and unsustainable revenue. Ensuring that jurisdictions do not become economically locked-in also requires investment mechanisms and trade deals reshaped to allow for imposed constraints on industry expansion into the future. However, under several international treaties, including NAFTA, investor protections can be invoked and oil and gas operators can challenge moratoria that reduce the value of their tenures [49]. In some jurisdictions, the state's capacity to step back from full development of resources in the future may already be compromised.

In light of the scale of natural gas resources and the path dependency of their development, Levi [50] suggests that natural gas is less a bridge than a "hedging tool" against the possibility that it will be more difficult to move away from coal, rather than a means to achieving global climate goals aligned to specific warming targets. This understanding of gas's potential is consistent with the scenarios explored above, which suggest that with less ambitious climate targets, gas could play a larger role in the energy mix for longer, though would still ultimately be supplanted by low carbon sources for base load generation. Since our hydrocarbon reserves exceed the carbon budget for remaining within current warming targets [51], the potential climate impacts of unconventional gas development can be fully understood only within the context of the full hydrocarbon energy portfolio. A full examination of various scenarios and probabilities for mitigation is beyond our current scope. However, unless we accept a higher degree of warming, it appears increased natural gas extraction and use provide only a short "bridge" - if any-before it must be curbed alongside other fossil sources in favour of renewables and low-carbon sources [50,52], and even under less ambitious scenarios, gas will need to be displaced by lower carbon sources before it is exhausted. We argue this situation raises challenging governance conditions, necessitating rigorous planning and shaping of the rapidly growing industry towards a clean energy system. 


\section{The Shale Gas Dilemma and the Role of the State}

The governance challenges that shale gas poses are thus not modest. In the above analysis, we find that integrating natural gas in a way that is consistent with longer-term climate stability not only requires more aggressive regulation of the industry, but also muscular leadership - presumably by the state - to shape energy system development into the future [53]. That mitigating climate change amidst a globalized and powerful fossil fuel industry poses a significant governance challenge is not new or surprising, of course; the lack of progress towards climate mitigation suggests as much. What we argue here is that while shale gas may (under some conditions) fall outside the conventional scholarship on fossil fuels and climate mitigation in its potential to reduce emissions by displacing coal, it is not exceptional to the vast political challenges of managing a novel fossil fuel industry animated by a growth imperative under geophysical conditions of climate change that require constraining and strategically shaping development [54,55].

In the context of the rise to dominance of neoliberal policy frameworks, with their emphasis on reducing the role of the state in the marketplace, the call for more muscular state action to regulate and shape the industry might seem almost fanciful [56]. In fossil-fuel producing jurisdictions, not only has the inclination of the state been overwhelmingly towards facilitating rather than constraining the industry, but political institutions themselves have been fundamentally shaped by the industry [57]. However, the role of the state within neoliberal policy frameworks has been varied and complex [58], with states in many contexts not so much retreating from regulation as simultaneously shifting the focus of their regulatory efforts and actually expanding their scope and scale, leading to what some scholars have called "regulatory capitalism" [59]. One of the defining characteristics of regulatory capitalism is the tendency of the state to hold on to the capacity to "steer" industry, even as the privatization of previously public responsibilities expands the role of the private sector [60]. In this context, the question becomes that of what role the state could play, or could be made to play, in the "steering" of shale gas development towards the goal of climate mitigation.

We argue the answer to this question resides in part in the evolution of resistance to shale gas. States do not engage industry in a vacuum: rapid expansion of the industry — with attendant impacts - is inspiring strong resistance to the environmental and economic deal offered by unchecked development. Resistance movements have played a crucial role in establishing moratoria on fracking in France, Bulgaria, Quebec, and the US states of New York and New Jersey. As shale gas production expands elsewhere, protest—and concerns raised-likewise expand.

Although resistance manifests and focuses differently across different jurisdictions, what is shared is concern about the pace and scale of development and its resultant impacts. In densely populated areas, emphasis falls on public health and water contamination, buoyed by peer-reviewed evidence of methane contamination from fracking [19] and acknowledgement of contamination through accidental leaks and spills [40]. Elsewhere, localized resistance targets the incompatibility of shale gas development and existing or desired climate legislation; landscape-scale impacts, especially in areas of high biodiversity; distribution of risks and benefits, especially in places where landowners do not directly benefit from exploitation on or near their property; lack of disclosure and monitoring of health effects of fracking fluids; potential violations of treaty rights in traditional lands of Indigenous peoples; and concerns about whether the public is receiving a fair deal from exploitation of public resources. 
Global resistance has varied, with organizations at times targeting industry on specific points, such as the universal implementation of green completions [61], and at other times focusing more generally on linking and supporting localized resistance [62].

While some of these concerns can be addressed by more robust regulation, transparency in how the industry operates, and effective public engagement, these steps are proving difficult for the state to implement, confronting the same barriers as effectively addressing climate mitigation described above: the difficulty of imposing costs on the industry amidst concerns over competitiveness, and an unwillingness to actively intervene in the market to shape, rather than facilitate, development. Although such constraints are excused in the name of public revenue, recent studies have questioned whether lack of control over the shale gas industry's pace and scale of development (too much, too fast) might ultimately undermine the industry's ability to deliver on promised public revenue $[22,63,64]$. This is not only because fierce competition has resulted in a glut, low prices, and falling demand [65], but also because of the structure of the market in current regulatory contexts. A recent New York Times article suggests that a market correction to resolve oversupply has been stymied by investment mechanisms that tie operators to contracts to produce more, even at a loss, raising questions the financial viability in many American drilling operations - the most advanced worldwide $[63,66]$. Proponents argue the market will "self-correct," but critics have characterized this as an "Enron moment" - the building of a bubble — in part because of inadequate regulatory oversight [35].

In short, the industry, and governments who depend upon the revenue it generates and seek to facilitate its expansion, are facing a tangle of challenges at many sites, many of which - not surprisingly - point to the need for more effective governance of the industry to ensure that it can operate in the public interest. As long as these concerns persist, and resistance flourishes, it feeds the wider and deeper concerns about whether the industry should be allowed to expand at all, regardless of its capacity to operate in ways that are consistent with climate mitigation. Wide-ranging confidence exists that the inexpensive energy that the industry will produce will be enough to ensure its long-term viability. This may indeed be the case: tighter regulations, more transparency in their enforcement, and demonstrated public benefits will go a long way towards increasing the industry's social licence to operate. These steps will not be adequate to ensure that the industry is being developed and operating in ways consistent with climate mitigation in the longer term; however, the open question is whether resistance to the industry that pressures states on local governance concerns might also enhance the state's capacity for managing gas development for climate change; and if so, how states might themselves evolve to manage the multifaceted dilemma of abundance brought on by shale gas.

The answers to these questions are still unfolding, and undoubtedly will vary across jurisdictions. However, focusing down to the regional level, we can already begin to see how the governance challenges identified above lead to fundamental dilemmas for the state. We now turn to focus on a specific context - British Columbia, Canada - to illustrate how the shale gas dilemma we sketch above manifests. British Columbia (BC) is not an entirely representative case; in many regards its industry is an outlier, as it is more remote, more export-driven, and less likely to displace domestic coal. But while the $\mathrm{BC}$ case is not representative of all governance challenges, the $\mathrm{BC}$ case is indicative of the magnitude of governance challenges that arise from novel shale gas developments: if $\mathrm{BC}$, a global leader for environmental policy, cannot reconcile its gas developments with climate mitigation aspirations, other jurisdictions will likely face commensurate challenges. With a large environmental 
constituency, $\mathrm{BC}$ is also a key site to explore how resistance to unchecked development may constraint the industry, or steer it towards improved governance; or, conversely, how the state may seek to contain resistance.

\section{The Shale Gas Dilemma in British Columbia, Canada}

British Columbia's shale gas reserves are massive, accounting for half the technically-recoverable shale gas resources in Canada [67,68]. The reserves are located in the remote northeastern corner of the province, an area already impacted by industrial development, including forestry, mining, conventional natural gas, and large-scale hydroelectric dams. Declines in resource industries (particularly forestry and fisheries) have strained rural communities and economies across the province, generating a search for alternative sources of economic prosperity. Conveniently, much of the northeast is covered by Treaty 8, which was signed in 1899 not least to facilitate industrial development in the region [69-71]. The absence of outstanding Aboriginal rights and title claims in the region potentially makes the process of large-scale industrial development much smoother, although constitutionally-protected treaty rights still must be respected.

Resistance to its resource extraction industries has rendered $\mathrm{BC}$ a hub of environmental activism, and site of many innovative and transformative strategic approaches to environmental challenges [72]. The province has taken a leadership role in relation to climate mitigation, with legislated emissions reduction targets (of 33\% from 2007 levels by 2020 and an $80 \%$ reduction from 2007 levels by 2050), a carbon tax (currently at $\$ 30 /$ ton), and a commitment to maintain $90 \%$ of its electricity generating capacity from GHG-free sources [73].

Under these conditions, BC's shale gas development has appealed heavily to the legitimizing argument that the province can maintain its global leadership role on climate mitigation, promoting its natural gas as a "climate solution" to aid a transition fuel to a low carbon global economy through export of liquefied natural gas (LNG) to coal-burning Asian nations, where natural gas commands a far higher price [74]. Development has proceeded rapidly. For example, 426 shale gas wells were drilled in one shale gas reserve (the Montney Play) in 2011 alone [75]. The scale of individual fracking jobs has also been impressive: in 2010 Apache completed a hydraulic fracturing job almost four times larger than any other of its kind in North America [76]. In February 2012, the Province launched an ambitious Natural Gas Strategy that articulates the broader vision for the future of the industry [74], which includes rapidly expanding the industry over the next ten years. Pending environmental approval, the $B C$ Jobs Plan also commits the province to have the first LNG plant in operation by 2015 and three LNG facilities operating by 2020 [74].

The fast pace of this industry ramp up is matched by fast-paced developments elsewhere, and BC is racing to compete. As new shale gas reserves are discovered around the world, inspiring new actors to enter what is already a competitive field, the question arises of whether the price differential that makes Asian markets so attractive will persist. Lack of demand, oversupply and a weak commodity price remain concerns [77]. In a reflection on the uncertainty about the viability of the industry, we note that while there are five pipeline and terminal projects with varying stages of approval and apparent pressure to move quickly to gain advantage in the marketplace, the industry has not made final investment commitments. 
Nonetheless, the rapidly developing industry has enjoyed bipartisan support from the Liberal government and the New Democratic Party in opposition [78], both pleased to tout the prospective revenue and job creation. (The Province is anticipating 1,000-2,000 more jobs from the natural gas industry within the next five years and promised \$398 million in revenue from gas royalties in 2012) [79].

Drawing from the analysis above, we identify technical and governance challenges for reconciling climate mitigation and shale gas development in $\mathrm{BC}$, before exploring implications.

\subsection{Governance Challenges for Reconciling Shale Gas and Climate Action in BC}

Above, we identify the key challenge of scientific uncertainty and debate on the climate impacts of shale gas; at the level of jurisdictional governance, this uncertainty is both implicated in and extended by regulatory frameworks that omit or ignore climate impacts of novel shale gas development. BC, despite its leadership on climate policy, lags on characterizing (and managing) the climate impacts of its emergent shale gas industry. A loophole in the province's carbon tax policy means it applies only to combusted fuel, exempting upstream emissions, which are estimated to account for $10 \%$ of total lifecycle emissions [80], and formation $\mathrm{CO}_{2}$, which must be stripped from natural gas before piping and is vented directly to the atmosphere. At $12 \%$ of production, formation $\mathrm{CO}_{2}$ is unusually high in BC's largest and most productive reserve, the Horn River Basin, although the smaller Montney Play has lower than average formation $\mathrm{CO}_{2}$ [81].

To reduce uncertainty and better characterize climate impacts, the Province should include lifecycle emissions in provincial GHG accounting and the carbon tax (see [80,82]). Including upstream emissions under the carbon tax would encourage producers to employ emissions reductions technologies. This policy direction would benefit from further primary research to measure upstream emissions (e.g., implement and expand monitoring of non-combustion fugitive emissions and leaks; support and produce scientific field and modeling studies examining fugitive emissions and formation $\mathrm{CO}_{2}$ impacts specific to $\mathrm{BC}$ context), though best available estimates would still be an improvement over omission. However, at present, the province lacks capacity for such monitoring and evaluation, and uncertainty about the scale of emissions impacts and omission from provincial GHG accounting processes plays an enabling function in allowing the Province to delay imposing the costs of the carbon tax on the industry.

Characterizing the lifecycle climate impacts of shale gas and losing the carbon tax loophole would mark an important first step towards the Province living up to its claim that it will "maintain leadership on climate change and clean energy" [83]. However, BC can undertake other no-regrets steps to reduce emissions, the second key policy challenge we identify above. Given that $\mathrm{BC}$ wishes to export its gas, and has no coal-fired generation to replace domestically, its potential for shaping the political-economic context towards emissions reductions must focus on reducing upstream emissions, and aiding other jurisdictions in managing downstream emissions. Upstream, early expansion of the industry was justified in part by a promise to use renewable energy to power LNG facilities. The Premier has since revised this decision to suggest renewable energy may be used where feasible, opening the possibility of using natural gas itself, with its attendant emissions, but if $\mathrm{BC}$ was serious about reducing emissions, it could revisit use of renewable energy for liquefaction terminals and assess the relative impacts of using renewable energy and natural gas. $\mathrm{BC}$ could also improve accountability about venting/flaring 
policy [26], explore potential for green completions technologies, and consider a requirement for Carbon Capture and Storage of formation $\mathrm{CO}_{2}[84]$.

However, the Province has shown little willingness to impose any additional costs on the industry, which is already working at thin margins: as inexpensive natural gas has flooded the market in North America, the price has plummeted to historic lows. The actual risks of imposing additional costs to the industry are questionable; as the Pembina Institute's Matt Horne suggests, "If adding a few percent to the cost of BC LNG exports (natural gas is currently selling for close to \$15 per gigajoule in Asia) makes these projects infeasible, then the business case is already so rickety that we shouldn't be taking the risk" [82]. However, this remains a concern for politicians. Even if emissions are measured and taxed, the fact remains that BC's targeted expansion in gas production is irreconcilable with legislated climate targets (barring rapid deployment of CCS, which is not currently being considered) [85]. This dilemma has not been seriously engaged, with politicians relying on the case that $\mathrm{BC}$ gas, while increasing emissions domestically, will reduce them globally.

The international case for exporting $\mathrm{BC}$ gas to support emissions reductions and aid in broader energy system transformation is questionable. As an exporter, $\mathrm{BC}$ 's capacity to reduce emissions, and its main contribution towards situating shale gas within a broader clean energy systems transformation, will come from its capacity to effect climate benefits within the international energy system. However, although LNG may still outperform coal-fired generation, it requires additional liquefaction, transport, and re-gasification, which make up $18 \%-21 \%$ to lifecycle emissions, making LNG's benefit - especially when produced from higher-emissions shale gas-more limited [17,86,87]. Even then, in an international market, there is no guarantee BC's unconventional sources will contribute to mitigation. The IEA suggests that while fuel-switching and coal displacement is succeeding in the USA, it is "unlikely that LNG will displace coal in Asia. Rather LNG is more likely to add to overall capacity in an expanding energy market" [88]. In other words, there is no easy path to ensuring that BC's gas contributes to appropriate infrastructural development elsewhere.

Inter-jurisdictional cooperation will be a first step in ensuring BC's exported gas actually displaces energy sources with higher GHG emissions and helps reshape the broader energy system towards mitigation. BC's situation as an exporter reaffirms the need for effective regional and global carbon pricing. Though this goal remains illusive, $\mathrm{BC}$ has pursued regional cooperation on climate mitigation in the past through the Western Climate Initiative. Enhancing this cooperation to strengthen and deepen the carbon-pricing regime would help to ensure that the unconventional gas industry develops in ways that will be sustainable in a future low-carbon regulatory framework. Despite this, BC faces real limits in its capacity to shape downstream impacts, and current political discourse has not broached this topic. Horne [82] suggests levying a carbon tax on exported emissions and investing in climate mitigation, but acknowledges this would render the BC industry uncompetitive and would require coordinated support and adoption of other LNG exporters, and alternatives (such as investing in mitigation in export regions) seem unlikely to win public or political support.

More immediately, BC's ability to shape downstream policy may best be shown by its own commitment to climate action and capacity to lead by example by maintaining a credible leadership role in environmental policy. Turning to discuss BC's current governance regime for shale gas, we find that this is not assured. 


\subsection{Discussion of $B C$ case}

Eager to benefit from potential revenues from the industry, and well aware of the intensely competitive environment for the industry, both federal and provincial levels of governments have aggressively pursued an agenda of facilitating rapid expansion of fossil fuel development, particularly focused on expanding export capacity.

At the provincial level, government is actively promoting the industry with royalty credits targeting shale gas producers, public investment in road building, and fast-tracked support for development of LNG infrastructure [74]. However, existing legislation does not cover crucial concerns about shale gas production. BC lacks a framework for managing for cumulative impacts of industrial development, despite the layers of historical resource extraction (forestry, conventional gas, mining) in this global biodiversity hotspot [89]. The Auditor General of BC released a report stating that the government is not doing enough to protect biodiversity, particularly with respect to habitat conservation [90]. Provincial water legislation is outdated (and under revision), with water allocation processes particularly inadequate; comprehensive baseline water quality testing is not required; and shared governance frameworks are not in place for regions (such as the northeast) where multiple users rely on water resources [91]. With such concerns being raised more frequently, and the government appearing unwilling or able to address them, industry has sought to protect its social licence to operate through "beyond compliance" initiatives [92].

At the federal level, facilitation of rapid expansion of fossil fuel development has taken the form of aggressively attacking environmental groups who oppose pipeline and other industrial developments [93]; dismissing or reducing the power of independent advisory and oversight bodies related to climate mitigation [94]; and enacting changes in legislation to repeal environmental protections, facilitate industry expansion, and consolidate power. The omnibus budget bill of 2012 affected 70 laws, including the Canadian Environmental Assessment Act, Navigable Waters Act, National Energy Board, and Fisheries Act. Changes to the Environmental Assessment Act significantly reduce the number of projects that will be assessed (only "designated projects," as yet undefined, will be assessed) and, when an assessment happens, it will be subject to time limits that constrain the public's ability to participate. As a result, environmental assessments will now largely be conducted by the provinces, raising questions about the ability of provinces to substitute for federal oversight. In parallel, the Navigable Waters Protection Act, one of Canada's oldest federal environmental laws, was also rewritten in 2012. It is now the Navigation Protection Act (NPA), protecting navigation only and excluding $99.7 \%$ of Canada's lakes and more than $99.9 \%$ of Canada's rivers from federal oversight (it is estimated that Canada has over 2.25 million rivers, 62 of which are now protected under the NPA). In addition to this drastic reduction in the number of protected waterways, the NPA will no longer protect waterways from development that interferes with navigation. Instead, citizens will be obliged to bring common law action to protect any waterways being harmed by development [95].

At the same time as such changes remove federal protections, they also allow for a considerable concentration of power: the federal changes the Environmental Assessment Act also give the Canadian Environmental Assessment Agency (CEAA) the power to exempt even "designated projects" from undergoing assessment. The federal Cabinet can also now override a "no" decision of the National Energy Board, effectively gutting this independent advisory board (which already is no longer required 
to ensure measures have been taken to minimize impacts on species at risk before approving a pipeline or other major infrastructure) [96,97]. With these moves, the role of government at both the provincial and federal levels has been to facilitate industrial access and delay action on climate change, not to prioritize protection of natural resources.

In response, early expressions of concern about the expansion of the industry have started to harden into active resistance. Various stakeholders have raised perceptions of a lack of leadership, capacity and monitoring from the provincial government [98], and NGOs are beginning to take active stands on the issues surrounding shale gas development [84,99-102]. Early support for the industry from First Nations is also wavering: plans to fuel LNG plants with natural gas, instead of renewable sources from Independent Power Producers have drawn fire from coastal First Nations, who have concerns about air shed quality, emissions, and the loss of long-term benefits of renewable energy production. Upstream, the Fort Nelson First Nation (whose traditional territory encompasses the Horn River Basin) has recently gone public with a petition to mandate improved governance of water withdrawals [103], citing dissatisfaction with the current consultation process. There is growing collaboration between upstream and downstream First Nations, amidst a burgeoning solidarity movement concerning pipelines in $\mathrm{BC}$ (with rampant opposition to the proposed Enbridge pipeline to carry Alberta bitumen to tidewater), and nation-wide in protest to the budget bills that have dramatically altered legislation affecting First Nations and treaty rights [104]. The alignment between environmental groups and First Nations has a powerful catalyst for resistance movements in $\mathrm{BC}$ in the past, especially with regards to forestry $[105,106]$.

Forming the backdrop of such concerns is the question of at what level of benefits BC is prepared to facilitate the natural gas industry, and whether the industry can deliver on promised revenue in exchange for liquidating natural resources. The price of natural gas, measured in gigajoules (gJ), dropped to $\$ 2.15$ in 2012 (falling from $\$ 6.33 \mathrm{gJ}$ in 2008), with every 50-cent change in the price of natural gas reducing provincial revenues from between $\$ 72$ million to $\$ 110$ million. This drop in natural gas prices means a drop in revenue of $\$ 1.1$ billion over the next three years [107]. In an indication of how important natural gas revenue already is to the province, this caused a mid-year budget crisis as actual revenue in 2012 was much lower than expected. A variety of policy tools could be used to address the economic uncertainties associated with shale gas development, ensure that it is offering a fair deal to $\mathrm{BC}$ citizens, ensure that the province retains resilience in the face of the volatility of the industry, most focusing on taxation and royalty regimes, including consideration for how those revenues are channeled into public goods. At present, there is not a robust consultation process to solicit and respond to public concerns.

The constellation of concerns generating resistance thus includes not only landscape-level environmental impacts, but global climate change and the precedent BC sets; process-driven concerns over Aboriginal rights and title; and concerns about democratic legitimacy of revised legislation. The diversity of concerns raised about shale gas development - including many that exceed the imperatives of regulating the industry to be consistent with climate mitigation-show considerable convergence when it comes to charting a policy framework. Implementing robust cumulative effects assessment and management would help to address those concerns focused on landscape, water and air impacts of the industry. Involving those communities most immediately affected by development, to ensure that treaty rights are being respected, is particularly important in this regard, providing a context for 
citizens to articulate their priorities for how development should proceed, the tradeoffs they are willing to consider and the securities they require. Slowing the pace of development, revisiting the scale and scope of LNG infrastructure permitted, and allowing the industry to prove itself economically would also play a role. This would need to be supplemented by a strengthened regulatory and enforcement regime.

To date, these steps are not occurring. At this point even fairly modest regulation of the industry - such as cumulative impacts assessment, or emissions pricing-are perceived to threaten the economic viability of the industry, raising fundamental questions about the inclination and capacity of the state to engage in more muscular efforts to shape energy system development. To constrain the pace of development is perceived to be irreconcilable with the race to secure contracts producing for Asian markets amidst fierce international competition. Current governance institutions appear either constrained or unwilling to impose costs, actively control and shape development, or plan to scale back development in the future.

However, simply facilitating industry expansion brings about its own dilemma: resistance to the industry, combined with a wider perception that both provincial and federal governments are systematically ignoring or attacking existing legislation designed to protect the public's interest in natural resource management, threatens both the industry's social licence to operate and the governments' legitimacy, posing wider challenges for each. The wider challenges that mitigating climate change poses to our political institutions, and how these are intertwined with broader questions of environmental protection and social justice, become ever clearer, pushing towards a crisis point, or governance innovations that might ease these tensions. Either way, the challenge to the state is profound.

\section{Conclusions}

The $\mathrm{BC}$ case reveals that the emergence of abundant unconventional fossil fuels does not necessarily ease the challenges for states facing the need to mitigate climate change. Quite the contrary: abundant unconventional fossil fuels pose these challenges ever more intensely, revealing in particular the limitations of our current institutions of governance.

While $\mathrm{BC}$ is an exceptional case, the challenges in $\mathrm{BC}$ speak to global conditions for jurisdictions developing shale gas. If $\mathrm{BC}$ cannot regulate the industry, we suggest it is likely other jurisdictions will face the same constraints when struggling with intersecting technical and governance challenges of reconciling gas development and climate change mitigation, and of managing the benefits and impacts of the industry adequately to minimize resistance. Based on this analysis, we find that governance challenges surpass technical challenges of rendering unconventional gas consistent with climate mitigation, with current governance institutions constrained or unwilling to impose costs, actively shape development, or plan strategically to integrate gas development into a low carbon energy system.

These conditions produce a dilemma for the state, insofar as its failure to regulate the industry incurs growing resistance. Put differently, absent concerns about climate change, the challenges posed by ramping up the shale gas industry point to the need for a state with greater inclination and capacity to govern the industry in the best interest of its population. To the extent that this resistance also pushes towards governance of the industry in ways that are consistent with climate mitigation, the challenge posed to the state increases dramatically. As suggested above, the challenge of mitigating climate in an era of shale gas extraction points to the need for a different kind of state, one that is 
capable of judicious market intervention, long-term planning for energy system development with consideration for environmental sustainability, and enhanced inter-jurisdictional cooperation.

In our view, this is the dilemma that shale gas poses: in its abundance resides an abundance of governance challenges, challenges that extend far beyond the technical and even regulatory, and towards what the state will be in the era of climate mitigation. Crucially, the determining factor in whether or how the state moves towards effective governance in these areas will be public resistance, both to the shale gas industry specifically and to practices that compromise climate mitigation more generally.

\section{Acknowledgments}

The authors would like to thank Kate Garvie, Matthew Paterson, and especially Lindsay Monk for their help with this paper, and two anonymous reviewers for their very constructive feedback. Financial support for this research was provided by Carbon Management Canada.

\section{Conflict of Interest}

The authors declare no conflict of interest.

\section{References}

1. International Energy Agency (IEA). World Energy Outlook 2012; International Energy Agency: Paris, France, 2012.

2. All projections are for increased energy use through the 21 st century, corresponding with increases in both population and per capita consumption, and the IPCC projects that energy related GHG emissions, mainly from fossil fuel combustion, will rise by over 50\% between 2004 and 2030, from 26.1 GtCO2eq (7.1 GtC) to 37-40 GtCO2 (10.1-10.9 GtC). Sims, R.E.H.; Schock, R.N.; Adegbululgbe, A.; Fenhann, J.; Konstantinaviciute, I.; Moomaw, W.; Nimir, H.B.; Schlamadinger, B.; Torres-Martínez, J.; Turner, C.; et al. Energy Supply. In Climate Change 2007: Mitigation. Contribution of Working Group III to the Fourth Assessment Report of the Intergovernmental Panel on Climate Change; Metz, B., Davidson, O.R., Bosch, P.R., Dave, R., Meyer, L.A., Eds.; Cambridge University Press: Cambridge, UK and New York, NY, USA, 2007.

3. Energy Information Administration (EIA). Annual Energy Outlook 2012 with Projections to 2035; Energy Information Administration: Washington, DC, USA, 2012.

4. International Energy Agency (IEA). Key World Energy Statistics 2011; International Energy Agency: Paris, France, 2011.

5. International Energy Agency (IEA). World Energy Outlook 2010; International Energy Agency: Paris, France, 2010.

6. International Energy Agency (IEA). World Energy Outlook 2011: Are We Entering a Golden Age of Gas? International Energy Agency: Paris, France, 2011.

7. International Energy Agency (IEA). Energy Technology Perspectives 2012; International Energy Agency: Paris, France, 2012.

8. We speak of them as governance-rather than regulatory or policy-challenges primarily because of our skepticism that they can be addressed exclusively through conventional regulatory 
or policy instruments, for reasons we elaborate below. Although we document the general governance challenges that must be addressed, and the specific dilemma these pose to states, we here leave open the question of what kinds of institutions will be necessary to resolve them.

9. Howarth, R.W.; Santoro, R.; Ingraffea, A. Methane and the greenhouse-gas footprint of natural gas from shale formations. Clim. Chang. 2011, 106, 679-690.

10. Howarth, R.W.; Santoro, R.; Ingraffea, A. Venting and leaking of methane from shale gas development: Response to Cathles et al. Clim. Chang. 2012, 113, 1-13.

11. Wang, J.; Ryan, D.; Anthony, E.J. Reducing the greenhouse gas footprint of shale gas. Energ. Policy 2011, 39, 8196-8199.

12. Jiang, M.; Griffin, W.M.; Hendrickson, C.; Jaramillo, P.; van Briesen, J.; Venkatesh, A. Life cycle greenhouse gas emissions of Marcellus shale gas. Environ. Res. Lett. 2011, 6, 034014:1-034014:9.

13. Fulton, M.; Mellquist, N.; Kitasei, S.; Bluestein, J. Comparing Life-Cycle Greenhouse Gas Emissions from Natural Gas and Coal; Worldwatch Institute: Washington, DC, USA, 2011.

14. Cathles, L.M.; Brown, L.; Taam, M.; Hunter, A. A commentary on "The greenhouse-gas footprint of natural gas in shale formations" by RW Howarth, R. Santoro, and Anthony Ingraffea. Clim. Chang. 2012, 113, 525-535.

15. Cathles, L.M. Assessing the greenhouse gas impact of natural gas. Geochem. Geophy. 2012, $13,1-13$.

16. Burnham, A.; Han, J.; Clark, C.E.; Wang, M.; Dunn, J.B.; Palou-Rivera, I. Life-cycle greenhouse gas emissions of shale gas, natural gas, coal, and petroleum. Environ. Sci. Technol. 2012, 46, 619-627.

17. Hardisty, P.E.; Clark, T.S.; Hynes, R.G. Life cycle greenhouse gas emissions from electricity generation: A comparative analysis of Australian energy sources. Energies 2012, 5, 872-897.

18. Alvarez, R.A.; Pacala, S.W.; Winebrake, J.J.; Chameides, W.L.; Hamburg, S.P. Greater focus needed on methane leakage from natural gas infrastructure. Proc. Natl. Acad. Sci. USA. 2012, $109,6435-6440$.

19. Osborn, S.G.; Vengosh, A.; Warner, N.R.; Jackson, R.B. Methane contamination of drinking water accompanying gas-well drilling and hydraulic fracturing. Proc. Natl. Acad. Sci. USA. 2011, 108, 8172-8176.

20. Environmental Protection Agency (EPA). Inventory of U.S. Greenhouse Gas Emissions and Sinks: 1990-2009; Environmental Protection Agency: Washington, DC, USA, 2011.

21. Kinnaman, T.C. The economic impact of shale gas extraction: A review of existing studies. Ecol. Econ. 2011, 70, 1243-1249.

22. Urbina, I. Insiders sound an alarm amid a natural gas rush. The New York Times, 25 June 2011.

23. Davis, C. The politics of "fracking": Regulating natural gas drilling practices in Colorado and Texas. Rev. Pol. Res. 2012, 29, 177-191.

24. Jenner, S.; Lamadrid, A.J. Shale gas vs. coal: Policy implications from environmental impact comparisons of shale gas, conventional gas, and coal on air, water, and land in the United States. Energ. Policy 2013, 53, 442-453.

25. Depending on whether gas is vented or flared.

26. Stephenson, E.; Doukas, A.; Shaw, K. Greenwashing gas: Might a 'transition fuel' label legitimize carbon-intensive natural gas development? Energ. Policy 2012, 46, 452-459. 
27. Fugitive emissions are defined by the Intergovernmental Panel on Climate Change (IPCC) and the Inventory of U.S. GHG Emissions and Sinks as both intentional and unintentional emissions from systems that extract, process, and deliver fossil fuels (in contrast to intentional emissions designed into the equipment or system). Environmental Protection Agency (EPA). Greenhouse Gas Emissions Reporting from the Petroleum and Natural Gas Industry: Background Technical Support Document; Environmental Protection Agency: Washington, DC, USA, 2010.

28. The global warming potential of methane remains under investigation, with some recent estimates suggesting it is higher than previously thought. Shindell, D.T.; Faluvegi, G.; Koch, D.M.; Schmidt, G.A.; Unger, N.; Bauer, S.E. Improved attribution of climate forcing to emissions. Science 2009, 326, 716-718. Impacts of methane on the climate system are also under investigation and remain debated. Wigley, T.M. Coal to gas: The influence of methane leakage. Clim. Chang. 2011, 108, 601-608.

29. Forster, P.; Ramaswamy, V.; Artaxo, P.; Berntsen, T.; Betts, R.; Fahey, D.W.; Haywood, J.; Lean, J.; Lowe, D.C.; Myhre, G.; et al. Changes in Atmospheric Constituents and in Radiative Forcing. In Climate Change 2007: The Physical Science Basis. Contribution of Working Group I to the Fourth Assessment Report of the Intergovernmental Panel on Climate Change; Solomon, S., Qin, D., Manning, M., Chen, Z., Marquis, M., Averyt, K.B., Tignor, M., Miller, H.L., Eds.; Cambridge University Press: Cambridge, UK and New York, NY, USA, 2007.

30. Hughes, D.J. Lifecycle Greenhouse Gas Emissions from Shale Gas Compared to Coal: An Analysis of Two Conflicting Studies; Post Carbon Institute: Santa Rosa, CA, USA, 2011.

31. Pétron, G.; Frost, G.; Miller, B.R.; Hirsh, A.I.; Montzka, S.A.; Karion, A.; Trainer, M.; Sweeney, C.; Andrews, A.E.; Miller, L.; et al. Hydrocarbon emissions characterization in the Colorado Front Range: A pilot study. J. Geohys. Res. D 2012, 117(D4), D04304:1-D04304:19.

32. Tollefson, J. Methane leaks erode green credentials of natural gas. Nature News, 2 January 2013. Available online: http:/www.nature.com/news/methane-leaks-erode-green-credentials-of-naturalgas-1.12123/ (accessed on 6 March 2013).

33. For example, the field studies by Petron et al. [31] and Alvarez et al. [18] find that emissions from unconventional gas fields show significant site-to-site variability Alvarez et al. [18] analyzed 250 well sites in the Barnett Shale, and found that $10 \%$ of sites accounted for nearly $70 \%$ of emissions. Leak rates varied from $0-5 \%$, with six sites showing leak rates of $2.6 \%$ or greater due to routine emissions (not including well completions and blow downs, which add to overall lifecycle emissions of the well), while many others had no routine emissions.

34. Rogers, H. Shale gas - the unfolding story. Oxf. Rev. Econ.Pol. 2011, 27, 117-143.

35. Ahmed, N.M. The great oil swindle. Le monde diplomatique, March 2013. Available online: http://mondediplo.com/2013/03/09gaz/ (accessed on 6 March 2013).

36. Stephenson, T.; Valle, J.E.; Riera-Palou, X. Modeling the relative GHG emissions of conventional and shale gas production. Environ. Sci. Technol. 2011, 45, 10757-10764.

37. The production of independent, credible baseline information is the responsibility not only of government but of the academic scientific community, though this is also not without difficulty, with concerns over the credibility of academic research on shale gas also arising in the past years (for example, the University of Buffalo closed its Shale Gas Research Institute in 2012 after an internal assessment into whether the university had properly applied rules governing financial 
interests amid growing concern about the Institute's ties with industry). Navarro, M. "SUNY Buffalo Shuts Down Its Institute on Drilling." The New York Times, 19 November, 2012. Available online: http://www.nytimes.com/2012/11/20/nyregion/suny-buffalo-will-end-controversialfracking-institute.html?_r=0/( accessed on 14 March 2013).

38. For example, the Environmental Defense Fund has partnered with academic institutions including Harvard and Duke, and 8 energy companies including Shell and Southwestern, to produce a credible study on methane leakage that they estimate will be complete in December 2013. Pembina Institute. Shale gas in Canada: Background document for the Pembina Institute Thought Leader Forum. Pembina Institute: Vancouver, Canada, August 2012. Proposed US EPA regulations that would require reduction of methane emissions, which should begin to produce data in 2012, will further characterize the degree to which technological and regulatory fixes can affect the climate performance of unconventional gas and help control emissions from individual gas developments [11,18].

39. Rothkopf, D. Cursed with plenty. Foreign Policy 2013, 198, 95-96.

40. International Energy Agency (IEA). Golden Rules for a Golden Age of Gas; International Energy Agency: Paris, France, 2012.

41. Hilborn, R.; Walters, C.J. Uncertainty, resource exploitation, and conservation: Lessons from history. Science 1993, 260, 17.

42. Bradshaw, G.A.; Borchers, J.G. Uncertainty as information: Narrowing the science-policy gap. Conserv. Ecol. 2000, 4, 7.

43. Holling, C.S.; Berkes, F.; Folke, C. Science, Sustainability and Resource Management. In Linking Social and Ecological Systems: Management Practices and Social Mechanisms for Building Resilience; Cambridge University Press: Cambridge, UK, 1998.

44. US General Accountability Office (GAO). Federal Oil and Gas Leases: Opportunities Exist to Capture Vented and Flared Natural Gas, Which Would Increase Royalty Payments and Reduce Greenhouse Gases; US General Accountability Office: Washington, DC, USA, 2010.

45. America's Oil Bonanza. Available online: http://www.economist.com/news/leaders/21566663good-thingbut-it-would-be-better-if-energy-was-priced-correctly-united-states-americas/ (accessed on 6 March 2013).

46. United Nations Framework Convention on Climate Change (UNFCCC). Report of the Conference of the Parties on its seventeenth session, Durban, 28 November to 11 December 2011. Addendum Part Two: Action taken by the Conference of the Parties at its seventeenth session. Available online: http://unfccc.int/resource/docs/2011/cop17/eng/09a01.pdf (accessed on 14 March 2013).

47. Smil, V. Energy Transitions: History, Requirements, Prospects; Praeger: New York, NY, USA, 2010.

48. Meadowcroft, J. What about the politics? Sustainable development, transition management, and long term energy transitions. Policy Sci. 2009, 42, 323-340.

49. This has occurred in Quebec, where an American operator is suing under NAFTA Ch. 11 for lost income from its oil and gas tenures following the imposition of a moratorium on fracking. Gray, J. U.S. firm to launch NAFTA challenge to Quebec fracking ban. Globe and Mail, 15 November 2012. 
50. Levi, M. Climate consequences of natural gas as a bridging fuel. Clim. Chang. 2013, doi 10.1007/s10584-012-0658-3.

51. Meinshausen, M.; Meinshausen, N.; Hare, W.; Raper, S.C.; Frieler, K.; Knutti, R.; Frame, D.J.; Allen, M.R. Greenhouse-gas emission targets for limiting global warming to 2 C. Nature 2009, $458,1158-1162$.

52. Moniz, E.J.; Jacoby, H.D.; Meggs, A.J.M. The Future of Natural Gas: An Interdisciplinary MIT Study. Available online: http:/mitei.mit.edu/publications/reports-studies/future-natural-gas/ (accessed on 6 March 2013).

53. Debate exists, of course, about whether a state-driven regulatory approach is the best one for mitigating climate change, with some arguing that it is simply implausible or strategically naïve, and others that it is undesirable. In the latter case, the state usually remains an important agent for stimulating and shaping climate mitigation, but its role is one of facilitating private sector innovation and scale-up of appropriate technologies. Prins, G.; Galiana, I.; Green, C.; Grundmann, R.; Hulme, M.; Korhola, A.; Laird, F.; Nordhaus, T.; Pielke, R., Jr.; Rayner, S.; et al. The Hartwell Paper: A New Direction for Climate Policy after the Crash of 2009; LSE: London, UK, 2010. Given the character of resistance to shale gas development, as we discuss below, we emphasize a state-led regulatory approach here, but acknowledge the need for a more robust engagement with the diversity of roles states might play in governance of the industry.

54. Newell, P.; Paterson, M. Climate Capitalism; Cambridge University Press: Cambridge, UK, 2010.

55. Barry, J. Climate Change, 'The Cancer Stage of Capitalism' and the Return of Limits to Growth: Toward a Political Economy of Sustainability. In Climate Change and the Crisis of Capitalism; Pelling, M., Manuel-Navarrete, D., Redclift, M., Eds.; Routledge: New York, NY, USA, 2012; pp. 129-142.

56. Harvey, D. A Brief History of Neoliberalism; Oxford University Press: Oxford, UK, 2005.

57. Mitchell, T. Carbon Democracy: Political Power in the Age of Oil; Verso: London, UK, 2011.

58. Neynen, N., McCarthy, J., Prudham, S., Robbins, P., Eds. Neoliberal Environments: False Promises and Unnatural Consequences; Routledge: London, UK and New York, NY, USA, 2007.

59. Levi-Faur, D. Regulatory Capitalism: The dynamics of change beyond telecoms and electricity. Governance 2006, 19, 497-525.

60. Levi-Faur, D. The global diffusion of regulatory capitalism. Ann. Am. Acad. Polit. Soc. Sci. 2005, $598,12-32$.

61. Ceres. Available online: http://www.ceres.org/press/press-releases/investors-press-oil-and-gascompanies-to-reduce-and-report-risks-from-hydraulic-fracturing-operations/ (accessed on 5 March 2013).

62. Global frackdown homepage. Available online: http://www.globalfrackdown.org/ (accessed on 6 March 2013).

63. Krauss, C.; Lipton, E. In a Natural Gas Glut, Big Winners and Losers. The New York Times, 20 October 2012.

64. Weijermars, R.; McCredie, C. Inflating US shale gas reserves. Pet. Rev. 2011, 65, 36-38.

65. McCallion, P. US natural gas shale plays threaten Canadian export market. Energy Risk, 13 January 2010. Available online: http://www.risk.net/energy-risk/feature/1585754/us-natural-gasshale-plays-threaten-canada-export-market/ (accessed on 9 May 2013). 
66. Richter, W. Dirt cheap natural gas is tearing up the very industry that's producing it. Business Insider. Portland, 5 June 2012. Available online: http://mobile.businessinsider.com/capitaldestruction-in-natural-gas-2012-6/ (accessed on 6 March 2013).

67. British Columbia Natural Gas and Petroleum-Yours to Explore. Available online: http://www.empr.gov.bc.ca/OG/oilandgas/royalties/infdevcredit/Documents/YourstoExplore18M ar2010web.pdf (accessed on 6 March 2013)

68. National Energy Board. Canada's Energy Future: Energy Supply and Demand Projections to 2035; National Energy Board: Ottawa, Canada, 2011.

69. Ray, A.J. Treaty 8: A British Columbian Anomaly. BC Stud. 1999, 123, 5-58.

70. Fumoleau, R. As Long as This Land Shall Last: A History of Treaty 8 and Treaty 11, 1870-1939 (No. 5); University of Calgary Press: Calgary, AB, Canada, 2002.

71. Madill, D. Treaty Research Report Treaty Eight (1899); Treaties and Historical Research Centre, Indian and Northern Affairs Canada: Ottawa, Canada, 1986.

72. BC has been a hub in the development of market-based environmentalism, for example, which has led to important innovations in both the development and character of new governance institutions, for example, see $[105,106]$.

73. BC Energy Plan: A Vision for Clean Energy Leadership. Available online: http://www.energyplan.gov.bc.ca/ (accessed on 4 March 2013).

74. British Columbia's Natural Gas Strategy: Fueling B.C.'s Economy for the Next Decade and Beyond. Available online: http://www.gov.bc.ca/ener/popt/down/natural_gas_strategy.pdf (accessed on 4 March 2013).

75. Adams, C. Summary of Shale Gas Activity in Northeast British Columbia 2011. BC Ministry of Energy and Mines, Geoscience and Strategic Initiatives Branch, 2012. Available online: http://www.empr.gov.bc.ca/Mining/Geoscience/PublicationsCatalogue/OilGas/OGReports/Docu ments/2012/Summary\%20of\%20Shale\%20Gas\%20Activity\%20in\%20NEBC\%202011\%20Versi on\%20HQ.pdf (accessed on 21 January 2013).

76. Apache Corporation. Ootla Team Celebrates Largest Completions in North America. Arrows Newsletter, July 2010. Available online: http://www.apachecorp.com/News/Articles/ View_Article.aspx?Article.ItemID=1130/ (accessed on 6 March 2013).

77. Park, G. Gas Revolution no. 2: Canadian Shale. Pipeline Gas J. 2010, 237, 28.

78. With an election approaching in May 2013, and the opposition New Democratic Party leading in the polls, a change of approach by the provincial government is possible, although the NDP has strongly signaled their support for the industry, so it is as yet unclear what difference this might bring.

79. Estimates, fiscal year ending March 31, 2013. Available online: http://www.bcbudget.gov.bc.ca/ 2012/estimates/2012_Estimates.pdf (accessed on 4 March 2013).

80. Dowlatabadi, H. Briefing Note 2011-Lifecycle Analysis of GHG Intensity in BC's Energy Sources; Pacific Institute for Climate Solutions: Victoria, BC, Canada, 2011.

81. National Energy Board. A Primer for Understanding Canadian Shale Gas-Energy Note Briefing. National Energy Board Publications Office: Ottawa, Canada, 2009.

82. Horne, M. Three Musts if BC Wants to Ship Gas to Asia. The Tyee, 17 December 2012. Available online: http://thetyee.ca/Opinion/2012/12/17/BC-Gas-Exports/ (accessed on 4 March 2013). 
83. Liquefied Natural Gas: A Strategy for B.C.'s Newest Industry. Available online: http://www.gov.bc.ca/ener/popt/down/liquefied_natural_gas_strategy.pdf(accessed on 4 March 2013).

84. Bramley, M.J. Is Natural Gas a Climate Change Solution for Canada? Pembina Institute/David Suzuki Foundation: Vancouver, Canada, 2011.

85. Jaccard, M.K.; Griffin, B. Shale Gas and Climate Targets: Can They be Reconciled? Pacific Institute for Climate Solutions: Victoria, Canada, 2010.

86. Jaramillo, P.; Griffin, W.M.; Matthews, H.S. Comparative life-cycle air emissions of coal, domestic natural gas, LNG, and SNG for electricity generation. Environ. Sci. Technol. 2007, 41, 6290-6296.

87. Venkatesh, A.; Jaramillo, P.; Griffin, W.M.; Matthews, H.S. Uncertainty in Life Cycle GHG emissions from United States natural gas end-uses and its effects on policy. Environ. Sci. Technol. 2011, 45, 8182-8189.

88. International Energy Agency (IEA). World Energy Outlook 2011; International Energy Agency: Paris, France, 2011.

89. Forest Practices Board. The Need to Manage Cumulative Effects; Forest Practices Board Bulletin: Victoria, Canada, 2013; Volume 13.

90. Office of the Auditor General of BC (OAGBC). An Audit of Biodiversity in BC: Assessing the Effectiveness of Key Tools; Office of the Auditor General of BC, Report 10; Victoria, Canada, 2013.

91. Parfitt, B.; Baltutis, J.; Brandes, O.M. From Stream to Stream: Emerging Challenges for BC's Interlinked Water and Energy Sources; POLIS Project on Ecological Governance/Canadian Centre for Policy Alternatives: Victoria, Canada, 2012.

92. For example, the Canadian Association of Petroleum Producers has suggested a series of principles for fracking, including disclosure of water use and fracking fluid additives and baseline groundwater testing, but to date there is no 3rd party audit or legislation enforcing such practices. Canadian Association of Petroleum Producers (CAPP). Guiding Principles for Hydraulic Fracturing. 2012. Available online: http:/www.capp.ca/getdoc.aspx?DocId= 218125\&DT=NTV/ (accessed on 7 March 2013).

93. For example, in 2012 Natural Resources Minister Joe Oliver attacked environmental groups, calling them "radicals" who were trying to "hijack our regulatory system" using "funding from foreign special interest groups to undermine Canada's national economic interest.” Oliver, J. “An open letter from the Honourable Joe Oliver, Minister of Natural Resources, on Canada's commitment to diversify our energy markets and the need to further streamline the regulatory process in order to advance Canada's national economic interest." Natural Resources Canada: Ottawa, Canada, 9 January 2012. Available online: http://www.nrcan.gc.ca/media-room/newsrelease/2012/1/3520/ (accessed on 7 March 2013).

94. The omnibus budget bill of 2012 repealed the Kyoto Protocol Implementation Act and the National Round Table on Environment and Economy [NTREE] Act phases out the advisory NRTEE body.

95. Bill C-45 and the Navigable Waters Protection Act (RSC 1985, C N-22). Available online: http://www.ecojustice.ca/files/nwpa_legal_backgrounder_october-2012/at_download/file/ (accessed on 5 March 2013). 
96. What Bill C-38 means for the environment. Available online: http://www.blackoutspeakout.ca/ cms/uploads/budget-bill-top-10.pdf (accessed on 5 March 2013).

97. May, E. Bill C-38: The Environmental Destruction Act. The Tyee, 10 May 2012.

98. Angen, E.; Switzer, J. Shale Gas Thought Leader Forum Proceedings; Pembina Institute: Vancouver, BC, Canada, 2012.

99. BC's 2013 Budget: What are the True Costs of Natural Gas? Available online: $\mathrm{http}$ ://forestethics.org/blog/bcs-2013-budget-what-are-true-costs-natural-gas (accessed on 5 March 2013).

100. Stop Fracking! Available online: http://wildernesscommittee.org/fracking/ (accessed on 5 March 2013).

101. Lee, M. BC's Legislated Greenhouse Gas Targets vs. Natural Gas Development. Canadian Centre for Policy Alternatives BC Branch: Vancouver, Canada, 10 October 2012. Available online: http://www.policyalternatives.ca/natural-gas-ghgs/ (accessed on 5 March 2013).

102. Stop Fracking. Available online: http://canadians.org/water/issues/fracking/index.html/ (accessed on 5 March 2013).

103. Fort Nelson First Nation petition. Available online: http://www.change.org/en-CA/petitions/ premier-clark-don-t-give-away-our-fresh-water-for-fracking/ (accessed on 6 March 2013).

104. Denis, J. Why 'Idle No More' is gaining strength, and why all Canadians should care. Toronto Star, 20 November 2012. Available online: http://www.thestar.com/opinion/editorials/ 2012/12/20/why_idle_no_more_is_gaining_strength_and_why_all_canadians_should_care.html/ (accessed on 6 March 2013).

105. Shaw, K. The global/local politics of the Great Bear Rainforest. Environ. Polit. 2004, 13, 373-392.

106. Low, M.; Shaw, K. Indigenous Rights and Environmental Governance: Lessons from the Great Bear Rainforest. BC Stud. 2012, 172, 9-33.

107. Meissner, D. BC Budget Deficit Means Spending Cuts Coming: Finance Minister. Canadian Press, 13 September 2012.

(C) 2013 by the authors; licensee MDPI, Basel, Switzerland. This article is an open access article distributed under the terms and conditions of the Creative Commons Attribution license (http://creativecommons.org/licenses/by/3.0/). 